\title{
SUBJECT SPECIFIC PAEDAGOGIC (SSP) BASED ON HIGHER ORDER THINKING SKILL (HOTS) TO IMPROVE THE ABILITY OF SD TEACHERS IN SURAKARTA
}

\author{
Siti Istiyati, Kartono, Idam Ragil Widianto Atmojo
}

Universitas Sebelas Maret

sitiistiyati@staff.uns.ac.id

\section{Article History}

accepted 09/07/2018

approved 01/08/2018

published 17/09/2018

\section{Keywords}

Subject spesific pedagogic, High order thinking skill, Learning

\begin{abstract}
The purpose of this service is to train elementary school teachers in the administrative area of Surakarta city to have capabilities that are in accordance with the times or disruption era. In detail, the aim of this activity is to improve the ability of teachers to develop high order-based specific pedagogic $(S S P)$ subjects. thinking skill (HOTs). The subject of this service is an elementary school teacher in the city of Surakarta. The method used in this service begins the Workshop, Practices, and Implementation. In conducting this training the subjects were asked to work on tests related to the development of the SSS based HOTS. Analysis of the data used is pre-test and post-test. The result of this activity is that there is an increase in the knowledge and understanding of teachers regarding the development of SSS based on HOTs.
\end{abstract}

Social, Humanities, and Education Studies (SHEs): Conference Series https://jurnal.uns.ac.id/shes

p-ISSN 2620-9284

e-ISSN 2620-9292 


\section{PENDAHULUAN}

Pencapaian hasil pembelajaran yang optimal dan terbentuk siswa yang aktif, kreatif, inovatif, mampu berpikir tingkat tinggi serta memecahkan masalah membutuhkan guru yang kreatif dan inovatif yang selalu mempunyai keinginan untuk memperbaiki dan meningkatkan mutu proses belajar mengajar di kelas, karena dengan peningkatkan mutu proses belajar mengajar di kelas, mutu pendidikan dapat ditingkatkan. Oleh karena itu, upaya untuk memperbaiki dan meningkatkan mutu proses belajar mengajar harus selalu dilakukan.

Jika hasil belajar siswa rendah maka akan berakibat langsung pada kualitas pendidikan di Indonesia. Berdasarkan Undang-undang Nomor 14 tahun 2005 tentang guru dan dosen, dan Peraturan Pemerintah Nomor 19 tahun 2005 tentang standar nasional pendidikan, guru memiliki peran yang strategis dalam bidang pendidikan, jika guru-guru yang berkualitas dan profesional kurang maka peningkatan kualitas pendidikan di Indonesia sulit untuk terwujud dengan kata lain, guru merupakan ujung tombak dalam upaya peningkatan kualitas layanan dan hasil pendidikan. Untuk itu peningkatan kualitas pendidikan harus dilakukan melalui upaya peningkatan kualitas kompetensi paedagogik dan profesionalisme guru.

Sadar akan kualitas pembelajaran di Indonesia yang belum dapat memfasilitasi kemampuan berpikir tingkat tinggi (HOTS) para siswa, maka banyak upaya telah dilakukan oleh pemerintah Indonesia untuk melakukan perbaikan. Upaya-upaya tersebut di antaranya melakukan perubahan atau revisi kurikulum secara berkesinambungan, program kemitraan antara sekolah dengan Lembaga Pendidikan Tenaga Kependidikan (LPTK), proyek peningkatan kualifikasi guru, dan masih banyak program lain yang dilakukan untuk perbaikan hasil pendidikan tersebut.

Terkait dengan konteks pendidikan yang mengarah pada berbagai ide tentang reformasi yang dikaitkan dengan strategi yang mendukung proses berpikir tingkat tinggi menempati porsi yang substansial untuk diajarkan di kelas. Hal ini dikarenakan Higher Order Thingking Skill (HOTS) merupakan pondasi dalam pembelajaran sesuai hakikatnya, yakni proses (process), produk (products) dan sikap (attitudes). Dengan demikian, sesuai hakikatnya pembelajaran idealnya mengacu pada kegiatan pembelajaran yang memungkinkan peserta didik dapat memberdayakan potensi berpikir mereka secara maksimal. Melalui pembelajaran yang berbasis berpikir tingkat tinggi (HOTS) diharapkan siswa menjadi lebih kritis, kreatif, inovatif dan mampu memecahkan masalah sesuai dengan tuntutan abad 21.

Untuk mengatasi belum maksimalnya pembelajaran yang dilakukan guru, perlu dilakukan kegiatan yang mampu memfasilitasi guru melakukan kajian terhadap perangkat pembelajaran (subject spesific paedagogik) yang terdiri dari rencana pembelajaran, media, materi, lembar kerja siswa dan instrumen penilaian apakah sudah memfasilitasi HOTS para siswa? pemaduan prinsip HOTS dalam menyusunan subject spesific paedagogik (SSP) yang sesuai dengan kurikulum 2013 dapat dilakukan melalui kegiatan workshop. SSP merupakan perangkat pembelajaran lengkap yang terdiri dari rencana pembelajaran (RPP), materi pembelajaran, media pembelajaran, lembar kerja siswa atau kelompok, dan instrumen penilaian.

Upaya-upaya telah dilakukan secara intensif, tetapi pengemasan pendidikan sering tidak sejalan dengan hakikat belajar dan pembelajaran. Praktik-praktik pembelajaran hanya dapat diubah melalui identifikasi terhadap cara-cara guru belajar dan mengajar serta menganalisis dampaknya terhadap perolehan belajar siswa. Agar hal ini terjadi, sekolah perlu menciptakan suatu proses yang mampu memfasilitasi para guru untuk melakukan kajian terhadap materi pembelajaran, model dan metode pembelajaran, serta strategi-strategi mengajar secara sistematis, sehingga dapat memfasilitasi siswa untuk meningkatkan perolehan belajar. 
SHEs: Conference Series 1 (1) (2018) 799-805

Program-program atau model-model pengembangan profesionalisme guru membutuhkan fasilitas yang dapat memberi peluang kepada mereka learning how to learn dan to learn about teaching. Model pembinaan yang dapat mengembangkan dan meningkatkan profesionalisme pendidik melalui pengkajian pembelajaran secara kolaboratif dan berkelanjutan berlandaskan prinsip-prinsip kolegialitas dan mutual learning untuk membangun learning community dikenal dengan Lesson study (LS). LS dilaksanakan dalam tiga tahapan, yaitu merencanakan (plan), melaksanakan (do), dan merefleksi (see) secara terus menerus dan berkelanjutan. Implementasi lesson study secara berkelanjutan membantu guru mempercepat peningkatan kompetensi paedagogik dan profesionalismenya. Saat ini di sekolah dasar menggunakan kurikulum 2013 yang berbasis tematik dengan mengedepankan pendekatan scientific dan adapula SD yang masih menggunakan kurikulum KTSP. Meskipun demikian, guruguru SD dituntut untuk segera menyelaraskan dan meningkatkan kemampuan profesionalismenya dalam mengajar terutama mengimplementasikan pembelajaran yang dapat memfasilitasi berpikir tingkat tinggi siswanya. Melalui kegiatan LS diharapkan guru-guru yang sudah mengikuti pelatihan implementasi kurikulum 2013 dan guru yang sudah mengikuti pelatihan tentang implementasi pembelajaran berbasis HOTS yang diselenggarakan oleh LPPM, Dinas Pendidikan serta lembaga yang berkonsentrasi dalam meningkatkan profesionalisme guru seperti USAID Prioritas diharapkan dapat melakukan pembinaan profesi pendidik melalui pengkajian pembelajaran secara kolaboratif dan berkelanjutan berlandaskan prinsip-prinsip kolegialitas kepada guru-guru yang lain melalui kegiatan LS.

Indikator-indikator peningkatan profesionalisme guru melalui pelaksanaan lesson study dapat dilakukan melalui pengembangan perangkat pembelajaran (SSP) yang mengimplementasikan pembelajaran HOTS. LS terdiri dari siklus plan-do-see yang memungkinkan guru untuk dapat mengembangkan pemikiran kritis dan kreatif tentang belajar dan pembelajaran, proses sharing pengalaman berbasis pengamatan pembelajaran memberi peluang bagi guru untuk mengembangkan keterbukaan dan peningkatan kompetensi sosialnya, dan proses-proses refleksi secara berkelanjutan merupakan suatu proses bagi guru untuk meningkatkan kesadaran akan keterbatasan dirinya.

Berdasarkan hasil observasi dan wawancara yang dilakukan pada tanggal 24 Januari 2018 pada 2 orang kepala sekolah (SD Negeri Mangkubumen Kulon 83 Surakarta dan SD Negeri Purwotomo Surakarta) diperoleh hasil bahwa pengetahuan dan kemampuan guru untuk menyusun subject spesific paedagogik (SSP) atau perangkat pembelajaran yang memfasilitasi berpikir tingkat tinggi bagi siswanya masih rendah. Dari 40 orang guru yang di 2 sekolah tersebut hanya 2 orang guru $(5,7 \%)$ yang sudah mendapatkan pelatihan tentang pembelajaran berbasis HOTS, $12(34,3 \%)$ orang sudah mengetahui namun belum pernah mengimplementasikan dan $23(65,7 \%)$ orang guru yang masih belum mengetahui, belum pernah mengikuti pelatihan/workshop apalagi mengimplementasikan pembelajaran berbasis HOTS.

Agar proses penyelarasan kemampuan tentang pembelajaran tematik pada semua guru mitra dapat berlangsung dengan cepat, maka diperlukan suatu model pembinaan antar teman sejawat melalui pengkajian pembelajaran secara kolaboratif dan berkelanjutan berlandaskan prinsip-prinsip kolegialitas untuk berkolaborasi dan merancang lesson (pembelajaran) dan mengevaluasi kesuksesan strategi-strategi mengajar yang telah diterapkan antara guru yang sudah memahami pembelajaran yang memfasilitasi HOTS dengan guru yang masih kurang sebagai upaya meningkatkan proses dan perolehan belajar siswa.

Lesson Study (LS) merupakan salah satu strategi pengembangan profesi guru dengan prinsip mengembangkan pembelajaran secara bersama-sama, salah seorang guru ditugasi melaksanakan pembelajaran, guru lainnya mengamati belajar siswa. Proses ini dilaksanakan selama pembelajaran berlangsung. Pada akhir kegiatan, guru- 
guru berkumpul dan melakukan tanya jawab tentang pembelajaran yang dilakukan, merevisi dan menyusun pembelajaran berikutnya berdasarkan hasil diskusi.

Permasalahan rendahnya kemampuan guru tersebut harus segera diatasi, karena begitu pentingnya keterampilan guru dalam menyampaikan materi ajar yang sesuai dengan tuntutan kurikulum. Berdasarkan Undang-undang Nomor 14 tahun 2005 tentang guru dan dosen, dan Peraturan Pemerintah Nomor 19 tahun 2005 tentang standar nasional pendidikan guru memiliki peran yang strategis dalam bidang pendidikan, jika guru-guru yang berkualitas dan profesional kurang maka peningkatan kualitas pendidikan di Indonesia sulit untuk terwujud. Guru merupakan ujung tombak dalam upaya peningkatan kualitas layanan dan hasil pendidikan, untuk itu peningkatan kualitas pendidikan harus dilakukan melalui upaya peningkatan kompetensi paedagogik dan profesionalisme guru.

Namun kenyataannya menunjukkan bahwa belum semua guru di SD Mitra yang memahami, mengerti dan melaksanakan pembelajaran yang memfasilitasi HOTS dan berbasis kurikulum 2013. Hal ini antara lain disebabkan karena belum semua guru dapat mengikuti pelatihan implementasi kurikulum 2013. Menyikapi kurikulum yang baru ini, guru-guru SD dituntut untuk segera menyelaraskan dan meningkatkan kemampuan profesionalismenya dalam mengajar. Melalui kegiatan LS diharapkan guru-guru yang sudah mengikuti pelatihan implementasi kurikulum 2013 dan pernah mengikuti pelatihan model pembelajaran berbasis HOTS dibantu tim IPM dan sudah mengetahui, memahami, serta melaksanakan pembelajaran di kelasnya dapat melakukan pembinaan melalui pengkajian pembelajaran secara kolaboratif dan berkelanjutan berlandaskan prinsip-prinsip kolegalitas kepada guru-guru yang lain melalui kegiatan LS.

Berbagai upaya telah dilakukan pihak sekolah guna meningkatkan pemahaman dan kemampuan guru tentang pembelajaran yang memfasilitasi HOTS yang sesuai dengan kurikulum 2013 guna menyiapkan siswa di abad 21, diantaranya dengan mengirimkan guru-guru untuk mengikuti pelatihan dan mendatangkan narasumber. Namun berbagai upaya yang telah dilakukan pihak sekolah belum menampakkan hasil yang optimal, hal ini dikarenakan pelatihan-pelatihan yang diberikan belum menyentuh pada kegiatan praktik langsung (mengimplementasikan) atau melihat contoh pembelajaran yang menggunakan model pembelajaran berorientasi HOTS dan berbasis kurikulum 2013 secara langsung (guru model) sehingga guru-guru akan lebih jelas dan mengerti. Upaya lain yang dirasa dapat meningkatkan kompetensi guru bidang profisional dan paedagogil yaitu dengan menggabungkan workshop penyusunan perangkat pembelajaran (SSP) hingga mengimplementasikannya di kelas melalui kegiatan LS.

\section{METODE}

Subjek dalam pengabdian ini terdiri guru-guru sekolah dasar yang ada di wilayah administrasi kota Surakarta. Metode yang digunakan dalam pelatihan ini Workshop, Praktik, dan Implementasi. Teknik pengumpulan data menggunakan teknik tes. Teknik analisis yang digunakan menggunakan pre test dan post test.

\section{HASIL DAN PEMBAHASAN}

Berdasarkan hasil pre test yang dilakukan sebelum pelaksanaan kegiatan pengabdian menunjukkan bahwa guru-guru sekolah dasar di Surakarta yang terlibat sebagai peserta dalam kegiatan pengabdian dengan jumlah 50 guru yang terdiri dari lima sekolah dasar di kota Surakarta menunjukkan bahwa kemampuan guru dalam menyusun SSP berbasis HOTs masih rendah. Hal ini ditunjukkan dari data yang menyatakan bahwa masih terdapat 32 guru atau sebesar $64 \%$ belum tuntas dalam 
mengerjakan soal pre test terkait dengan penyusunan SSP berbasis HOTs di dalam pelaksanaan pembelajaran, atau hanya sekitar 18 guru $(36 \%)$ yang berhasil lulus. Guru yang berhasil lulus dalam pre test di dominasi oleh guru-guru muda yang masih hangat dengan ilmu-ilmu pendidikan terbaru, sedangkan guru-guru senior sedikit kesulitan dalam mengikuti kegiatan yang terkait dengan ilmu-ilmu pendidikan terbaru. Setelah dilaksanakan workshop tentang penyusunan SSP berbasis HOTs kemampuan guru dalam menyusun SSP berbasis HOTs meningkat dengan tingkat ketercapaian ketuntasan mencapai $86 \%$ atau sekitar 43 guru berhasil lulus dan sekitar 7 guru yang belum berhasil lulus. Hal ini menunjukkan terjadinya peningkatan sekitar $50 \%$ dari pre test ke post test yakni dari 18 guru menjadi 43 guru atau sekitar 25 guru. Secara grafis dapat dilihat dalam grafik 1.1 berikut:

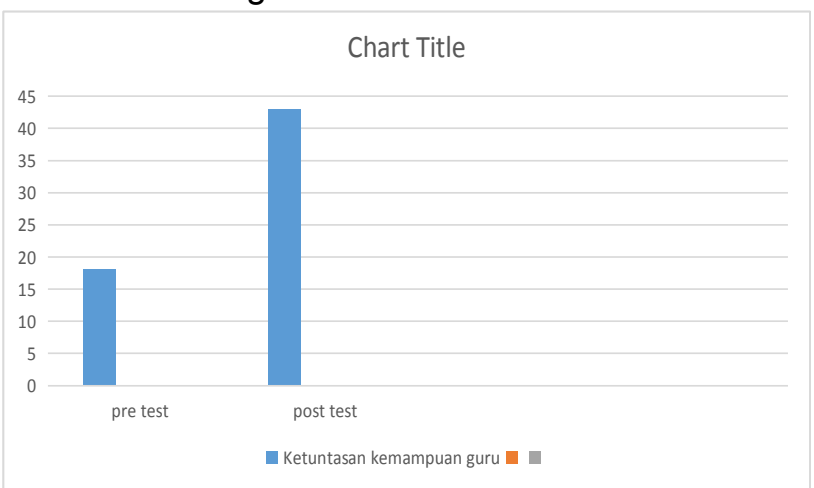

\section{Gambar 1.1 Grafik Hasil perbandingan pre test dan post test kemampuan guru SD}

Berdasarkan hasil pre test dan post test yang telah dilakukan ditemukan fakta bahwa pelatihan yang dilakukan memberikan dampak yang signifikan terhadap kompetensi guru. Pelatihan yang diberikan tentang penyusunan SSP berbasis HOTs memberikan dampak yang signifikan terhadap kemampuan guru dalam hal penyusunan SSP. Kegiatan workshop atau pelatihan dengan mendatangkan narasumber ahli yang merupakan pakar di bidang tersebut secara tidak langsung sudah memberikan dampak yang positif melalui proses komunikasi yang baik. Sebagaimana dijelaskan dalam Rosmawaty (2010) bahwa komunikasi kelompok adalah komunikasi dalam kelompok kecil orang, dengan tujuan antara lain untuk berbagi informasi, membantu mengembangkan gagasan bahkan membantu untuk memecahkan masalah, baik secara formal maupun tidak formal. Situasi formal yang dibangun ketika pelaksanaan Pelatihan atau Workshop akan membantu menyelesaikan permasalahan yang dihadapi oleh guru dalam hal penyusunan SSP yang berbasis pada HOTs..

\section{SIMPULAN}

Berdasarkan dari hasil kegiatan pelatihan atau workshop dapat disimpulkan bahwa dengan pelaksanaan workshop tentang penyusunan SSP berbasis HOTs dapat meningkatkan kemampuan guru dalam menyusun SSP berbasis HOTs yang akan digunakan dalam pelaksanaan pembelajaran. Simpulan ini didapatkan dari hasil analisis pre test dan post test yang dilakukan ketika pelaksanaan kegiatan.. 


\section{DAFTAR PUSTAKA}

Abruscato. (1982). Teaching children science. New Jersey: Printice-Hall, Inc

Anderson, W. L \& Krathwohl. R. D. (2001). A taxonomy for learning, teaching and assesing: A revision of bloom's taxonomy of educational objectives. New York: Addison Wesley Longman, Inc

Bloom, S. B., Engelhart, D. M., Furst, J. E., Hill, H. W., \& Krathwohl, R. D. (1956). Taxonomy of educational objectives, book I: Cognitive domain. New York: David McKay Company, Inc

Borg, R. W., \& Gall, D. M. (1989). Educational research: An introduction (4nd Edition). Boston:Pearson Education, Inc.

Brierton, S. B. 2011. Higher order thinking skills as demonstrated in synchronous and asynchronous online college discussion posts. Dissertation: North Carolina State University (Published). http://www.repository.lib.ncsu.edu/ diakses tanggal 05 januari 2015.

Carin, A. A., \& Sund, R. B. (1989). Teaching science through discovery. Columbus: Charles E. Merrill Publishing Company

Costa, L. A. (2008). Describing the habits of mind. In L. A. Costa., \& B. Kallick. (Eds.), Learning and leading with habits of mind; 16 essential characteristics for success (pp. 15-41). USA: Association for Supervision and Curriculum Development (ASCD)

D'Aurio, B. (2013). Introduction the flowscore: a digital ecosystem analytics framework (online). www.thinkinc.com diakses 10 januari 2017

Dewey, J. (1933). How we think: A restatement of the relation of reflective thinking to the educative process. Boston: D. C. Heath and Company.

Fisher, A. (2009). Berfikir kritis: Sebuah pengantar. Jakarta: Erlangga

Florida, R., Mellander, C., \& King, K. (2015). The Global Creativity Index 2015. London: Rottman Publisher

Gokhale, A. A. (1995). Collaborative learning enhances critical thinking [Online]. Journal of Technology Education, 7 (1). http://scholar.lib.vt.edu.sci-hub.org/ejournals/JTE/v7n1/gokhale.jte-

v7n1.html?ref=Sawos. Org diakses tanggal 1 Januari 2017

Halpern, D. F. (2003). Thought and knowledge: An introduction to critical thinking (4nd Edition). New Jersey: Lawrence Erlbaum Associates Publisher

Hart Research Associates. (2013). It takes more than a major: Employer priorities for college learning and student success for teaching and learning. New York: Cambridge University Press

Jujun S Suriasumantri. (2005). Filsafat ilmu: sebuah pengantar populer. Jakarta: Pustaka Sinar Harapan

Kauchak, D. P, \& Eggen, P. D. (1998). Learning and teaching: research based method (3nd Edition).Boston: Allyn and Bacon

King, F. J., Goodson, L., \& Rohani. (2006). Higher order thinking skills. Center for Advancement of Learning and Assessment

Lewis, A., \& Smith, D. (1993). Defining high order thinking. Theory Into Practice, 32 (3): 131-137

MartinProsperity Institute. (2015). The global creativity index 2015. http://martinprosperity.org/content/the-global-creativity-index-2015/. Diakses 1 Januari 2017

Marzano, R. J., Brandt, R. S., Hughes, C. S., Jones, B. F., Presseisen, C. S., Rankin, S. C., \& Suhor, C. (1988). Dimensions of thinking: A framework for curriculum and instruction. Alexandria, VA: Association for Supervision and Curriculum Development. 
Marzano, R. J., \& Pickering, D. J. (1997). Dimensions of learning. Colorado: Association for Supervision and Curriculum Development.

McGregor, D. (2007). Developing thinking; developing learning: A Guide to developing thinking in education. New York: Open University Press

Miri, B., Ben-Chaim, D \& Zoller, U. (2007). Purposely teaching for the promotion of higher-order thinking skills: A case of critical thinking. Res Sci Educ 37: 353-369

Moseley, D., Baumfield, V., Elliot, J., Gregson, M., Higgins, S., Miller, J., \& Newton, D. (2005). Frameworks for thinking: A handbook Osman, K., Hamid, S., \& Hasan, A. (2009). Standard setting: inserting domain of the 21st century thinking skills into the existing science curriculum in Malaysia. Procedia Social and Behavioral Sciences 1: 2573-2577

Muhibbin Syah. (1995). Psikologi pendidikan: Suatu pendekatan baru. Bandung: Rosdakarya Offset

National Research Council. (1996). National science education standards. Washigton, D.C: National Academic Press

National Science Teacher Association. (2003). Standards for science teacher preparation. http://www.nsta.org/pdfs/NSTAstandards2003.pdf diakses 14 Juni 2016

Nuryani Rustaman. (2008). Trend penilaian IPA di masa depan; inovasi penilaian hasil belajar dalam IPA. Bandung: UPI. http://www.p4tkipa.org/jurnal/index.html diakses 10 Januari 2016

Omrod, J. E. (2012). Human learning. (7nd Edition). USA: Pearson Education, Inc.

Polya, G (1973). How to solve it: A new aspect of mathematical method (2nd Edition). Princeton, New Jersey: Princeton University Press.

Resnick, B. L. (1989). Education and learning to think. Washington. D.C: National Academic Press

Rosmawanty HP. (2010). Mengenal Ilmu Komunikasi. Widya Padjadjaran

Soh, T., Asyad, N., \& Osman, K. (2010). The relationship of 21 st century skills on students' attitude and perception towards physics. Procedia Social and Behavioral Sciences 7(C): 546-554

Teare, B. (2005). Effective resources for able \& talented children. New York: Continuum International Publishing Group

The Learning Curve. (2014). Index - Which countries have the best schools? http://thelearningcurve.pearson.com/index/index-ranking. diakses 5 januari 2017

Undang-Undang Republik Indonesia No 20 Tahun 2003 Tentang Sistem Pendidikan Nasional. Bab 1 Pasal 1 Ayat 20 [Online]. www.inherentdikti.net/files/sisdiknas.pdf. diakses 10 Maret 2015

Zohar, A., Degani, A \& Vaaknin, E. (2001). Teachers' beliefs about low-achieving students and higher order thinking. Teaching and Teacher Education, 17, 469485

Zoller, U., \& Pushkin, D. (2007). Matching higher-order cognitive skills (HOCS) promotion goals with problem-based laboratory practice in a freshman organic chemistry course. Chemistry Education Research and Practice, 8 (2): 153-171 